\title{
Girrrl power and boyyy nature: the past, present, and paradisal future of consumer gender identity
}

\author{
Jacqueline J. Kacen \\ Visiting Assistant Professor of Business Administration, University of Illinois at \\ Urbana-Champaign, Champaign, Illinois, USA
}

\section{Keywords}

Advertising, Consumer behaviour, Gender, Post-modernism

\section{Abstract}

The new, Spice Girl-less millennium, "offers an opportunity to wipe the slate clean, to abandon concepts, models and formulations once thought liberatory now considered incarceratory; to start afresh on the other side of the year 2000". Foremost among the concepts to be updated is gender identity. In a postmodern society, traditional notions of femininity and masculinity come across as antiquated and illusory. The consumption ethic has deconstructed the historical malefemale mind-body producerconsumer dichotomy and made identity construction a consuming pastime. It has also turned gender into a pastiche of possibilities. Yet in the utopian cyber future that awaits us, what will become of gender identity? In the ethereality of the Internet, where existence is ephemeral, is gender identity a meaningful and necessary concept? This paper reviews the historical (modern) significance of gender identity to marketing, explores the postmodern consumer condition, and prophesies a paradisal vision of gender identity in the consumer society to come.
Marketing Intelligence \&

Planning

18,6/7 [2000] 345-355

(C) MCB University Press [ISSN 0263-4503]

\section{Introduction \\ Millennial endings, even more than centurial ones, given rise to millennial imaginings (Kumar, 1993).}

There is something about a new millennium that prompts theorizing about dramatic shifts and new directions, apocalyptic pronouncements about the death, and revelationary insights about the birth, of ideas, social structures, and/or institutions. Now that we have entered the new millennium, we are faced with a possible future and the task of "painting pictures of the putative promised land that lies before us. Or possibly behind us" (Brown, 1999a, p. 6). If the end of the twentieth century was a time for reflection, ruminations, and reevaluation, the new millennium offers "an opportunity to wipe the slate clean, to abandon concepts, models and formulations once thought liberatory now considered incarceratory; to start afresh on the other side of the year 2000" (Brown, 1999a, p. 6). Now is the time to propose, pursue, and portend paradisal visions of a new consumer society.

To that end, this paper addresses itself directly to the reformation of "gender identity" as it is constructed and signified in consumer society by proposing a utopian vision of a gendered paradise that is radically different from the existing social order and presumes "to render its inhabitants happier in some significant sense of that ambiguous yet unavoidable word" (Manuel, 1966, p. 70). Consistent with Utopian tradition, the paradisal vision of the new society presented here describes "a new state of being in which contemporary values in at least one area the critical one for the utopian - are totally transformed or turned upside down" (Manuel and Manuel, 1979, p. 8). Since gender identity is fundamental to the existing social order, its future significance is the focus of this paper.

\section{Gender and the new (?) consumer} society

It is a postmodern truth, universally acknowledged, that a single consumer in possession of a good fortune must be in want of a life.

Marketing has always been about consumption; gender has always been about differences. In the modern marketing era, up to the middle of the twentieth century, these two systems seemingly (and seamlessly?) worked in tandem to promote and encourage a consumption ethic in which men produced and women consumed. However, in the postmodern era, the ascendence of a culture of consumption has destroyed masculinefeminine differences by making everyone a consumer. In postmodernity, distinction through symbolic differentiation underlies the cultural system (Bourdieu, 1984) and consumption plays a central role in the construction of consumer identities.

One result of all this consumption activity is that the concept of gender identity $-\mathbf{a}$ concept long held inviolate by Western society, and used to great success by advertisers, manufacturers, and other cultural gatekeepers - is undergoing radical transformation. Traditional modern views of gender and gender identity are no longer credible. The old male-female, mind-body, producer-consumer distinctions are gone (Firat and Venkatesh, 1993). Masculinity and femininity are a bricollage of scattered meanings and shifting significances.

It is unlikely that the process of gender deconstruction will stop here. In cyberspace, individuals can change themselves as easily

The research register for this journal is available at http://www.mcbup.com/research_registers/mkt.asp
The current issue and full text archive of this journal is available at http://www.emerald-library.com 
Jacqueline J. Kacen Girrrl power and boyyy nature: the past, present, and paradisal future of consumer gender identity

Marketing Intelligence \& Planning

18,6/7 [2000] 345-355 as they change their clothes (Taylor and Saarinen, 1994). In this "virtual culture," the "real self" is replaced by a "virtual self," community by cybernetwork, human contact by electronic impulse. How can gender identity, which depends on socially created and agreed upon distinctions, have a place in the abstract, disembodied space of the Internet where social interaction exists only as the digital production and consumption of zeros and ones? In this environment, where the consumer is "an autonomous microparticle" (Baudrillard, 1996, p. 106) is there a role for gender? In the Utopian Web-wired future that awaits us, gender may lose all signification and cease to exist.

\section{Gender identity defined}

One is not born, but rather becomes, a woman (Simone de Beauvoir).

How we think of ourselves as men or as women comprises the fundamental core of gender identity. The term gender - one's masculinity and/or femininity encompasses the associations and meanings we attach to behaviors, attributes, and feelings of men and women[1]. Our phenomenological experience of being masculine or feminine, reflects the very being of our self-structure. To the extent that we, as individuals, develop an image of ourselves as male or female and convictions about what membership in that group implies, we have developed a gender identity (Yorburg, 1974).

While gender identity is a psychological construct, it is also a social construct that reflects the cultural context in which we live. "Gender identity - the understanding that one is a boy or a girl - doesn't come like a label attached to the genitals .... How we categorize ourselves depends on where we are and who is with us" (Harris, 1998). Gender identity is determined by a society's distinct sense of what is "essential" to, and characteristic of, one or the other sex class. Although distinct from "sex," a biological construct, gender is often confounded with and viewed as inseparable from - being male or female.

Our various conceptualizations and constructions of gender identity get expressed, signified (in a Saussurean sense), and conventionalized through roleappropriate behaviors, associated physical characteristics, occupations, and personality traits. One way individuals "become gendered" is through encounters with roles and stereotypes; socio-cultural institutions such as family, language, education systems, and the media help to promote and mold gender identity. The construction of gender identity occurs early in human development. By the age of two, a child has substantial gender knowledge and can use the words "girl" or "boy" correctly in referring to him/ herself (Katz, 1986). We are made aware of our gender at an early age, and once our core gender identity is formed it is hard to change (Katz, 1986; West and Zimmerman, 1998). Physical appearance plays a particularly significant role in gender construction (Tseelon, 1995). How we look is an extremely prominent cue for gender definition and social reaction/interaction.

The concept of gender and gender identity is significant because not only does every society develop a concept of gender and gender-appropriate traits, behaviors, and characteristics, but also these conceptualizations impact the basic workings of society. Regardless of other normative distinctions made, all societies distinguish between male and female, and all societies provide institutionalized genderappropriate roles for men and women (Gilmore, 1990). These conventional ideals and prescribed rules of behavior become the guiding principles by which individuals are judged "worthy" members of one or the other sex. The attendant images and models associated with each gender become psychological anchors or identities for most individuals, and serve as a basis for selfperceptions and self-esteem (D'Andrade, 1974)[2]. Even if a person does not identify with appropriate gender-typed traits or rejects traditional role definitions, he/she still learns the behaviors expected of him/her as a man or woman (Spence and Helmreich, 1978). Socially determined ideals of masculinity or femininity influence all our activities.

At its essence, gender identity is about hierarchical differences between men and women. The historical tendency has been to view men and women as embodying opposite and mutually exclusive traits. "'Masculinity' and 'femininity,' at least since the nineteenth century and arguably before, have been constructed through a process of mutual exclusion" (Bordo, 1993, p. 174). Gender distinctions are revealed in dominance/ power relations, social position, and the formation of basic personality traits (Stewart, 1998). In Western cultures, stereotypically masculine traits and characteristics like authority, power, aggression, competition, and domination have been valued over stereotypically feminine traits and characteristics such as compassion, sensitivity, and intuition and 
Jacqueline J. Kacen Girrrl power and boyyy nature: the past, present, and paradisal future of consume gender identity

Marketing Intelligence \& Planning

18,6/7 [2000] 345-355 have provided the foundation for capitalistic, corporate, and militaristic societies (MacKenzie, 1994). In this social system "masculinity" is glorified and "femininity" devalued. (For more detailed discussions of this dichotomous view of gender see Bordo, 1993; Gledhill, 1997; Hirschman, 1993; Firat, 1998; Joy and Venkatesh, 1994; Szirom, 1988; Thompson and Hirschman, 1995; and Tseelon, 1995.)

These distinctions between the meanings and representations of masculinity and femininity that have been assumed to be "essential, universal (at least within contemporary Western culture), highly dichotomized, and enduring" (Hare-Musten and Marecek, 1998, p. 128) were actually institutionalized by the social processes that arose in the eighteenth century. The emphasis on reason and objectivity that characterized the "Age of Enlightenment" marked the conceptual watershed for gender identity. Prior to the nineteenth century, men were considered the fashionable sex and young male bodies were eroticized as much as female ones (Tseelon, 1995). But the Industrial Revolution created profound social changes that resulted in women becoming domesticated, objectified, and constrained and men being aggrandized, empowered and dominant. This new economic system that separated the home from the workplace created a set of beliefs about the capabilities and propensities of men and women. Men's proper and natural sphere was increasingly seen as operating outside the home in the technologically modern workplace while women's proper and natural place came to be associated with the home, beauty, and domesticity (Marchand, 1985). Modern marketing practices promoted this view.

\section{Modern marketing and gender identity past}

Particular discourses create particular truths (Foucault, 1980)

Consumption has always been gendered. Consumer society developed within a culture that distinguished between men and women, and masculine and feminine, on almost every issue imaginable; consumption was no exception. From the early Victorian household manuals popular among the middle classes in the nineteenth century to the "masses" targeted by advertisers in the twentieth century, the ideal consumer has always been female (Bocock, 1993; Firat and Venkatesh, 1993; Marchand, 1985). As a 1929 Printer's Ink advertisement boldly proclaimed, "The proper study of mankind is man ... but the proper study of markets is woman" (Marchand, 1985, p. 66). For most of marketing's modern history, women have been seen as consumers and consumption as a feminine activity, while men have been seen as producers (working outside the home, "making" a living) and production as a masculine activity.

The ideal consumer, that is, women, was seen by advertisers and manufacturers as emotional, irrational, and lacking in selfcontrol. "In fact, nearly every characteristic commonly attributed to the masses was also conventionally a 'feminine' trait -

capriciousness, irrationality, passivity, and conformism" (Marchand, 1985, p. 69).

Consumption was seen as an evil, albeit a necessary evil, by manufacturers and advertisers; those who engaged in consumption practices were seen as weak and fickle. This "self-indulgence of the masses and feminine appetites for frivolous goods" was a threat to the work ethic and "to the vision of a rational, uplifting modernity" (Marchand, 1985, p. 160). Modern marketers maintained this rather disdainful attitude towards their targeted consumers even while designing and promoting products to encourage repeated and loyal consumption by them. The rise of "style goods," products that incorporated aesthetic or "fashion" elements, were designed to encourage greater and more frequent consumption. But "women were viewed as virtually the sole buyers of 'style goods.' To incorporate style into a product was to give it a 'feminine appeal"' (Marchand, 1985, p. 131).

The rise of modern advertising played a critical role in both reflecting and shaping this distinctly gendered view of men and women. The visual media - especially magazine advertisements - exert a form of "cultural leadership" in defining masculinity and femininity because of their ability to shape and promote/communicate consensual images (McCracken, 1993). Visual media are particularly effective in habitualizing and maintaining gender stereotypes because people are less likely to monitor their responses to pictures than to words (Archer et al., 1983; Unger and Crawford, 1992). Visual images inspire greater belief and arouse less psychological resistance than text, and because, as Marshall McLuhan observed, people do not approach pictures with feelings of insecurity and distrust as they do with words (Baker, 1961; McLuhan, 1951), advertisements are powerful promoters of the dominant view of society. Through stylized portrayals of characters, objects, and images, advertisements contribute to our 
Jacqueline J. Kacen Girrrl power and boyyy nature: the past, present, and paradisal future of consume gender identity

Marketing Intelligence \& Planning

18,6/7 [2000] 345-355 understanding of what masculinity and femininity are and influence our conception of gender identity.

Modern advertisements have presented a constricted view of masculinity and femininity. Particularly for women, the admitted target of most modern advertising (Marchand, 1985), the representations and images in magazine advertisements implied that domestic roles and an attractive appearance were the natural and appropriate occupations for women (Currie, 1997). Many ads portrayed women in the home working to keep the house clean and themselves beautiful. An Old Dutch Cleanser ad from 1931 showed a white-coated male scientist with a stop watch observing a woman cleaning a sink. The copy encouraged its reader to "Help yourself to more time. Science shows the way. Old Dutch Cleanser Cleans Quicker." The "scientific authority" portrayed in the ad was male (Marchand, 1985, p. 170). A 1926 ad for floor polish admonished, "By Their Floors Ye Shall Judge Them. It is written that floors are like unto a mirror, reflecting the character of the housewife" (Marchand, 1985, p. 171). Purchasing the right modern household products, it was supposed, would help women manage the household in an appropriately efficient and capable manner. Femininity became synonymous with domesticity, cleanliness, and caretaking.

A great majority of modern advertisements aimed at women focused on the importance of remaining young and beautiful. A 1912 ad for Sanitol Tooth Powder has a headline that reads "Exquisitely Dainty." The copy continues: "Bright eyes, rosy cheeks, coral lips - and now for the final touch to unspoiled beauty - glistening white teeth."[3]. Ads for Gala lipstick that ran in popular periodicals in Britain during the Second World War suggested wearing lipstick to support the war effort: “A woman's lips are key to her character ... a little lipstick gives added character to the mouth and added selfconfidence to the wearer. It is for this reason that the makers of Gala continue to manufacture this famous lipstick and suggest its use in moderation is an asset to our wartime morale." Victory through lipstick! Contemporary ads for products such as Revlon's age-defying makeup, Clinique's anti-aging serum, and Estée Lauder's Unline Total Eyecare that hold out the promise of eternal youth are merely continuing a long modern tradition of socializing women into gender identities that emphasize physical beautification and a youthful appearance.

Modern advertising's portrayal of men and masculinity had its own set of problematic limitations. Men appeared in ads as husbands or as businessmen at work. Invariably, they were white, middle-class, and held unremarkable positions in whitecollar occupations. Working-class men only appeared as part of the ad's background setting, helping to demonstrate the manufacture or use of the product; they never appeared as consumers. "Not one motorist in a thousand, for instance, ever appeared in anything but a suit, tie, and hat or elite sporting togs" (Marchand, 1985, p. 189). The competitive business world was what made a man a man, any other role portrayal would undermine his masculinity. "A businessman exemplified efficiency and control. If a woman's modernity was primarily decorative, a man's was primarily functional ... By refusing to give men a distinct 'look' ... as consumers, they preserved the assumption that dominant male instincts for production and functional modernity would counter any decadent tendencies of the consumption ethic" (Marchand, 1985, p. 191). Such beliefs were expressed and maintained in subtle and ingenuous ways. So, for example, advertising convention prohibited a husband from appearing in the company of a refrigerator without the presence of his wife (Marchand, 1985, p. 271).

The distinctive characteristics ascribed to men and women - such as rational versus emotional, thoughtful versus impulsive, producer versus consumer, functional versus decorative - clearly reflected idealized notions that were not authentic. Advertising that appealed to men's reason and agency, and to women's emotionality and nurturance, that restricted men to the world of business, and women to the role of housewife, that viewed men as producers and women as consumers, did not cohere with a consumption-oriented society. The accelerated rise in the consumption ethic made it increasingly impossible to maintain the pretense of producer-consumer masculine-feminine conventions. It soon became increasingly obvious that "the relationship of the Masculine and the Feminine to real men and women is relatively arbitrary" (Baudrillard, 1970, p. 144).

The restrictiveness of this dualist perspective of gender is incompatible with a consumption ethic that turns both women and men into consumers, consumer identities into individual compositions, and gender into another consumption object. In postmodernity, consumers' consumption constellations reflect an ironic approach to 
Jacqueline J. Kacen

Girrrl power and boyyy nature:

the past, present, and

paradisal future of consumer

gender identity

Marketing Intelligence \&

Planning

18,6/7 [2000] 345-355 gender identity and demonstrate a revolt against traditional (modern) gender ideology.

\section{Postmodern marketing and gender identity present}

He can't be a man 'cause he doesn't smoke the same cigarettes as me (Mick Jagger).

One of the hallmarks of postmodernity is a preoccupation by consumers with refashioning their personal identities out of cultural materials (Gergen, 1991; Giddens, 1991; see also McCracken, 1988). "Personal identity is increasingly sought by the consumer, even in its fragmented forms, and recognized by others, not on the basis of what one produces but on the basis of what one consumes" (Firat and Venkatesh, 1993). In a postmodern society, products get used as tangible markers through which individuals create, transform, and reconstruct themselves as they actively engage in trying to create and maintain a sense of identity through the display of purchased goods (Baudrillard, 1988; Belk, 1988). People try to become the being they desire to be by consuming the items that they imagine will help to create and sustain their idea of themselves, their image, their identity (Bocock, 1993). Thus, postmodern consumers don't purchase clothing, food, art, furniture, or entertainment in order to express an already existing sense of themselves. Rather, people create a sense of who they are through what they consume. "Brands are how we figure out who we are" (Seabrook, 1999). Our postmodern identities, therefore, are both determined and enhanced by the cultural products in which we invest.

In a postmodern society gender identities, like personal identities, are individual creations: "I suggest that each person's sense of gender ... is an inextricable fusion or melding of personally created (emotionally and through unconscious fantasy) and cultural meaning. ... To understand and address fully any individual's gender identity requires investigation of a unique confluence of personal and cultural meaning" (Chodorow, 1996, pp. 217, 224). Individuals lay claim to a certain identity via the presentation of the self and the establishment and maintenance of this identity is a cooperative activity between the individual actor and the audience (Goffman, 1959). The identity is sustained so long as neither the audience nor the actor provides evidence that makes it seem untenable. If discrediting evidence appears, identity is spoiled.
Accepting gender as performance - what one does at particular times - rather than a permanent and immutable part of one's being (Butler, 1990) - makes it easy to see that gender identity isn't a fixed attribute but a fluid quality that shifts and changes in different contexts at different times. Conceptualized in this manner, our postmodern identities, gendered or otherwise, are not expressions of some authentic inner "core" self but are the dramatic effect of our consumption performances (cf. McCracken, 1988; see also Thompson and Hirschman, 1995).

In a postmodern consumer society, gender identity becomes a malleable cultural product, an instrument of self-expression. The subversive and ingenious manner in which the existing meanings of gender and gender identity are uncovered, transformed, and displaced causes masculine/feminine distinctions to lose their significance (in a Saussaurean sense). Postmodern consumers aren't merely recombining feminine and masculine traits to forge new identities; the very meanings of masculine and feminine are being actively deconstructed and reconstructed in order to create new, unique selves. Gender is an individual accomplishment, not a socially constructed one.

Media personalities like Madonna, RuPaul, Dennis Rodman, and Marilyn Manson, demonstrate in a convincing way that "gender is a kind of persistent impersonation that passes as the real" (Butler, 1990, p. x). Transvestites are particularly threatening to established social meanings because they challenge the orthodoxy of gender difference (Woodhouse, 1989). Cross-dressing reveals the distinctly - and falsely - naturalized aspects of gendered experience and exposes the fiction of the notion of a coherent gender identity. "In imitating gender, drag implicitly reveals the imitative structure of gender itself" (Butler, 1990). Under postmodernity, gender identity is no longer a simple, natural fact but a pastiche of possibilities.

If under modernity, marketers and advertisers sold products that provided prepackaged, preconstructed, gendered consumer identities, and consumers, through consumption of these products, maintained their identities by accepting these gendered prescriptions; then under postmodernity, the role of marketers and advertisers is to provide consumers with the raw materials with which consumers can construct unique identities. Masculinity and femininity become semiotic signs and artistic resources, component parts with which consumers can 
Jacqueline J. Kacen Girrrl power and boyyy nature: the past, present, and paradisal future of consumer gender identity

Marketing Intelligence \& Planning

18,6/7 [2000] 345-355 construct other possible selves.

Deconstructed into its discrete meanings and images, gender is merely another possible element to add to the identity mix.

Marketers encourage and promote genderblurring through advertising campaigns and the development and promotion of new products that ignore and consciously subvert traditional gender notions. Over time, products and advertisements strip gender meanings of their significance. A black and white Versace jeans ad portrays a slender female without makeup in a sleeveless undershirt, jeans, work gloves, and construction boots, wearing a fully-stocked tool belt, holding herself in the frame of a wall being constructed with two-by-fours. Tropicana promotes its Ruby Red Grapefruit juice with added calcium using an image of a woman in a black leather jacket, sitting on a motorcycle, drinking a glass of juice, with the copy: "You think ruby red is a dainty color? Feel these bones, pal.” An ad for Jim Beam Kentucky bourbon shows a woman drinking milk from the carton and urges women to "get in touch with their masculine side" while Tommy Hilfiger promotes "American Tartans" - its collection of skirts for men - by showing four young men in kilts, backs to the camera, arms around each others' shoulders. Perhaps the tagline should read, "get in touch with your feminine side." Johnson \& Johnson promotes its Acuvue Disposable Contact Lenses using a male soccer player covered in dirt as the spokesmodel: "Since I switched from glasses to Acuvue disposable contact lenses, my girlfriend reckons I'm more desirable. I put it down to the mud packs." The ad doesn't tout consumer benefits such as convenience or improved vision performance, but physical appearance and sexual desirability, and the message is targeted to men!

Advertisements such as the Acuvue ad, that use imagery and message appeals that resemble those found in advertisements directed toward women, redefine men's identities in terms of feminine concerns and expose the fact that men have become as much a part of consumerism as women. Their construction of a sense of who they are is accomplished as much through style, clothing, body image and the right look as is women's (Kellner, 1992). The growth of men's cosmetics products is further evidence of this gender-blurring. Clinique's Turnaround Lotion for Men “Helps a man's skin look healthy and fit. Firms up skin tone, reduces appearance of fine lines. Smooths skin for closer, more comfortable shave." M.A.C. Cosmetics' best-selling products to men include a tinted moisturizer, blot powder, shaving cream, and concealer (Fetto, 1999). A recent Loreal ad for its new men's haircolor product Feria ("dyes for guys") displays a very blond Brad Pitt look-a-like gazing out with a pouty, seductive stare. The male imagery used in contemporary print ads and television commercials are not as much macho as erotic, even narcissistic, and provide a stark contrast to the ideals of modern masculinity promoted by the Marlboro cowboy. Advertising that focuses on the male body conditions men to be concerned with their appearance turning them into manipulable, submissive objects a classically female role. "The American cowboy as cultural model was not supposed to care for or about appearances. He was what he was, hard-working, straightforward, and honest. He was authentic. Men who cared 'too much' about how they looked did not fit this model; the dandy was effete, a European invention, insufficient in masculinity and not red-blooded enough to be a real American." (Barthel, 1994). If the Marlboro man of modernity represented the masculine ideal, then the androgynous adolescents of Calvin Klein's cKOne and cKbe campaign are the poster children of postmodern gender identity.

The truth is, a postmodern consumer society that is obsessed with appearance and consumption, where style is a substitute for identity and presentation overshadows essence, is a culture that feminizes men. It turns "the male body from a site of production to a site of consumption" by displaying the male body as a sexual object, a historically feminine position (Brod, 1995; Tseelon, 1995). Fabio, "the Italianate romance model” is shown in an I Can't Believe It's Not Butter ad with his work shirt open to his chest delicately spraying the product on asparagus tips (Lippert, 1997). Men's magazines tout articles on "firm abs" and flaunt ads with half-naked men displaying perfect physiques in order to sell underwear (Ralph Lauren), cologne (Davidoff Cool Water), personal care products (Gillette), electronic goods (Samsung) and athletic gear (Nike). "Having a tight, sculpted stomach is a cherished goal of the Cosmo guy.... Since the practical effect of having steel abs is limited how many people see your stomach on any given day? - my guess is that the ab obsession arises because, just like women, men now want to look like the models in underwear ads" (Lowry, 1997). Men are the new babes. Postmodern pecsploitation!

The rise of advertising and marketing aimed at young men is part and parcel of the current enterprise boom in the service sector and media industries. But what is going on here is 
Jacqueline J. Kacen Girrrl power and boyyy nature: the past, present, and paradisal future of consumer gender identity

Marketing Intelligence \& Planning

18,6/7 [2000] 345-355 more subtle than advertising hype and profit motive. Young men are being sold images that rupture traditional icons of masculinity. They are stimulated to look at themselves and other men - as objects of consumer desire. They are getting pleasures previously branded taboo or feminine. A new bricollage of masculinity is the noise coming from the fashion house, the marketplace and the street (Mort, 1988, pp. 193-4).

Because masculine identities are vulnerable and easily threatened (Szirom, 1988), the postmodern emphasis on consumption and appearance is especially destructive. The technologization of war and the ascendance of women as independent wage earners in the workforce have diminished men's crucial identities as breadwinners and warriors (Brod, 1995; Ehrenreich, 1983). Cohan (1993) argues that macho film characters are responses to a profound but repressed cultural anxiety about the erosion of masculine virility in the twentieth century. "Mock-macho" situation comedies such as Home Improvement parody masculinity as a way to deal with "men's anxieties about a feminized ideal for manhood they may not want to live up to" (Hanke, 1998, p. 76). The recent phenomenal success of Viagra reflects men's obsession with impotence and can be taken as a further sign of men's increasing sense of vulnerability and inadequacy. The Men's Movements of the 1990s propagated the idea that men needed to "get in touch" with their masculinity. Retreating to fantasies of living as mountain men (Belk and Costa, 1998) help men to escape the problems of postmodernity.

In subverting traditional notions of masculinity, postmodernity makes transparent the masquerade of masculine and feminine identity. This dismantling of traditional ideologies reveals gender as "an identity tenuously constituted in time, instituted in an exterior space through a stylized repetition of acts" (Butler, 1990). Gender as a masquerade implies a lack of essence; it reveals that there is no essential gender identity, only masks and roles. Dismantling traditional gender ideologies allows (forces?) consumers to search for new meanings with which to construct a sense of self.

However, in a postmodern society, "the meanings of objects are no longer fixed and linked to their functions, but are free-floating as each individual may ascribe the meanings s/he desires to the objects" (Elliott, 1993, p. 136). If brand, product, and social meanings are constantly changing, can consumers truly use consumption objects to define and differentiate themselves? In a world awash in relativism, the universal search for a personal identity reaches new degrees of turbulence and uncertainty. "The postmodern context, with its emphasis on individual choice and consumer preferences ... creates a heady cocktail that seems quickly to befuddle and paralyze" (Lyon, 1999, p. 80). A postmodern consumer culture that is fragmented, dispersed, incoherent, and discontinuous is in an unstable disequilibrium state. Consumer identities are in constant flux. Postmodern society is a dystopia.

If there is no essential masculine and feminine nature, no fixed meanings, what becomes of gender identity as the postmodern is transformed into the postmillennial? Will this postmodern condition leave individuals in a permanent flux of relativity, where all is subject to only the arbitrary machinations of the marketplace (Lyon, 1999, p. 71)? Three possible utopias are proposed below[4].

\section{Marketing in the new millennium: paradisal visions of gender identity future}

The revolution is here, and it has bright-red toenails (Reilly, 1999).

\section{In Le Mythe de la Cite Ideale, Roger}

Mucchielli (1961, p. 170) defines utopia as "a myth, awakened by a personal revolt against the human condition in general in the shape of existing circumstances, which, meeting the obstacle of impotence, evokes in the imagination an other or nowhere, where all obstacles are removed." In a postmodern society, gender identity is in a state of chaos. Without the traditional (albeit restrictive) hierarchical structure of gender, consumers are left in an abyss of uncertainty.

One possible millennial future is that gender meanings continue to break down until all significance is lost. In the Web-wired future being foretold by media soothsayers and marketing pundits, the epicenter of social interaction will be the digital economy where electrons flow through computer chips made of sand (see e.g. Raymond, 1999; Wright, 2000). "During the past two years, the amount of time the average Internet user spends online each week has risen from 4.4 hours to 7.6 hours. If that annual growth rate, 31.5 per cent holds up, then in 2025 the average Internet user will spend 590 hours online per day" (Wright, 2000, p. 56; emphasis in the original). If all social interaction becomes electronically transmitted impulses, the very notion of gender may cease to have meaning. 
Jacqueline J. Kacen Girrrl power and boyyy nature: the past, present, and paradisal future of consumer gender identity

Marketing Intelligence \& Planning

18,6/7 [2000] 345-355
Computer-mediated communication (CMC) allows participants to conceal or mask identifying attributes such gender, age, and race. The cues which denote social hierarchies and gender attributes are not present in this medium and users are free to create new, different, and less normative identities. The use of pseudonyms and roleplaying are very common methods of managing one's identity in CMC forums (Jaffe et al., 1995). Pseudonymity allows "people to be other than 'themselves' or more of themselves than they normally express" (Danet and Ruedenberg, 1994). By using a pseudonym, an individual can ignore (violate?) gender-based norms without negative repercussions in either the "real" or the "virtual" world.

A study of CMC found that women had an increased tendency to mask their gender identity. More interestingly, pseudonym use resulted in greater expression of social interdependence among men (Jaffe et al., 1995). The authors speculated that "what we consider to be a 'feminine' pattern of exhibiting social interdependence might actually be an essentially human style unconstrained by the expectation of male power assertion." It appears that CMC can democratize communication while eliminating gender-based communication biases.

Given that gender identity is formed through social interactions and encounters with gender roles and stereotypes, and that physical appearance plays a significant role in gender construction, then in a future dominated by virtual reality and computermediated communication, gender becomes superfluous. An individual will have countless cyborg identities that may be donned or shed, muted or made more salient, depending on the "chat room" or virtual space he/she visits.

Of course, it is unlikely that society will escape from gender altogether in a cyberfuture. While sex, gender, and sexuality may be deconstructed in a postmodern society, they cannot be dispensed with (Lovell, 1996). Alternatively, a second utopian possibility is that the chaotic, unstable nature of postmodern identity construction will motivate a return to the past. "If all the postmodern can offer is randomness and chaos, play and pastiche, consumerism and unconcern ... critics might conclude that modernity held some attractions" (Lyon, 1999, p. 100). In a more and more individualistic and atomized society, the lack of community has to be compensated by the consumption of signs and symbols which reassures the individual of his/her identity and gives a social meaning to his/her life while giving him/her the illusion of belonging to a virtual community of consumers (Belk and Bryce, 1993). The progression towards a globalized, technologized consumer society may prompt a nostalgic longing for stability and structure that results in the revival of traditional gender ideologies.

There are signs in the marketplace that this phenomenon is already occurring. The Miller Brewing Company's ads for Miller Genuine Draft Beer promote the product's essential male nature with bold, in-your-face copy. R.J. Reynold's ads for Camel cigarettes evoke retro-gender-laced settings with images of Varga-like pinup girls, sailors on leave, and the classic male dick ...er ...detective. Toys ' $R$ Us new store design is an astonishingly direct example of the resurgence of target marketing based on traditional gender norms. Dolls, kitchen toys and makeup can be found on the magenta shelves in "Girl's World," while action figures, Tonka trucks, and walkie-talkies are stocked in "Boy's World” (Bannon, 2000). Mattel, Inc. now offers pink Barbie computer systems for cyber-girrrls and blue Hot Wheels computer systems for cyber-boyyys. Perhaps all this gender nostalgia is merely in keeping with the current retro-marketing phenomenon (see Brown, 1999b).

One holds out hope that these aberrant marketing strategies do not signal a return to an institutionalized gender system in which traits, beliefs, and behaviors are proscribed. Such a social system is devaluing and repressive. It precludes individuals from knowing a much wider range and greater complexity of desires, perspectives, and styles (Smith, 1992). With luck, the fragmentation, anxiety and incoherence of the postmodern condition precludes it. "As the overarching ideals of the modern era give way to the fluctuating, varied voices of the possibly postmodern, so any hopes of holding to a single way of being or a unified cosmos dwindle away" (Lyon, 1999, p. 76).

Postmodernity may be a poisoned chalice, but a return to modernity is certainly not the antidote.

Is the choice for a new millennial society between a restrictive gender identity or no gender identity? Must we live with traditional (modern) gender ideologies or can we move beyond them? How much is our notions of gender an authentic expression of human nature and how much a constructed reality?

The third, and final, utopian vision presented here assumes that gendered dimensions of human relationships exist. But 
Jacqueline J. Kacen Girrrl power and boyyy nature: the past, present, and paradisal future of consumer gender identity

Marketing Intelligence \& Planning

18,6/7 [2000] 345-355 it proposes that gender becomes something liberating, satisfying, celebratory. It holds out the possibility of gender as an ordinary, everyday experience of authenticity, of being true to oneself. "Technological transformations may be grasped, not as flights from reality, but as the means of creating new bodily and social realities, unimpeded by modern categories and constraints" (Lyon, 1999, p. 82). The success of strong, capable, yet feminine female television characters like Dana Scully ( $X$ Files) and Buffy Summers (Buffy the Vampire Slayer), computer-game heroes like Lara Croft, and the entire WNBA is evidence that gender ideals are changing. The US women's soccer team is a perfect embodiment of this postmillennial gender identity. The team has been described in Sports Illustrated as "a wonderful combination of Amazonian ambush and after-prom party ... [They] play technically perfect and emotionally riveting soccer. Not only that, but they try to score, as opposed to most men's teams, who try to get up one-nil and then pack 11 guys in their own box for 85 minutes. Nobody except the Pope put more fannies in the seats at Giants Stadium than the women's team did two weeks ago" (Reilly, 1999). Midfielder Brandi Chastain says, "We're women who like to knock people's heads off and then put on a skirt and go dance" (quoted in Reilly, 1999). These women reflect the gender-blurring that characterizes postmodern gender identities. As the media images we watch change, so too can our conception of gender norms.

Given that there is no essential essence to masculinity or femininity (Conley, 1984;

Kristeva, 1980), and that gender is constructed by culture and language (Lacan, 1977) then the emerging transformation, enhancement, and dilution of the culture that is occurring will continue to retextualize the meanings of gender. In the new millenium, gender identity will likely reflect a creolization of signs and significations, a mixing of what is at hand, the old and the new, something that "just happens" in an emergent fashion (Ger and Belk, 1996, p. 293). Given that gender is arbitrary and transcends the constraint of physical facts (Smith, 1992) then in the new post-millennial society individuals will be able to pick and choose different gender schemes or choose not to care about gender at all. Gender identity will become a pastiche, a random collection of traits and roles and behaviors that lack the familiar perceptible boundaries between men and women, a celebratory "medley" of potentialities.

\section{Conclusion}

All utopias are fated to be realized (Baudrillard, 1996).

This paper described, in a rather brief, arbitrary, and inchoate manner, the concepts, traditions, and historical accidents that have contributed to the conceptualization and construction of gender identity in Western societies. Whereas in the past, gender was a limited and limiting system of oppositions predetermined at birth that privileged masculine over feminine, for the present it appears that gender is merely a performance and gender identity merely a masquerade. To effect this masquerade, consumers use the products, materials, and artifacts available to them within a postmodern consumer culture. However, this postmodern identity construction process leads to a decentered and unstable sense of self. It is suggested that the result of this instability could lead to three possible postmillennial futures. A eutopian vision of the future was proposed in which gender identity undergoes a creolization process consumers will use whatever is at hand at the moment to fashion their individuality. In this paradisal post-millennial society, the oppositional structure of the past will no longer be discernible and masculinity and femininity will be a celebration of participative possibilities in this, the best of all possible worlds. "The great utopia startles and yet is recognized as conceivable. It is not a sleepy or bizarre vision but one that satisfies a hunger or stimulates the mind and the body to the recognition of a new potentiality" (Manuel and Manuel, 1979, p. 29).

\section{Notes}

1 Masculinity and femininity are used here in a socially constructed sense. The terms refer to a system of cultural practices, ideologies, and beliefs that inform the traits, roles, attitudes, behaviors and interpersonal orientation that have become historically associated with our conceptions of male and female. These latter terms imply inherent biological differences between the sexes (Bristor and Fischer, 1993; Epstein, 1988).

2 Interestingly, while passivity, dependence, and nurturing are the feminine norm, more "masculine" females have higher self-esteem (Williams, 1979). In addition, the emphasis on independence, ambition, competition, success, and invulnerability that characterizes masculinity creates its own set of problems for men who find themselves unable to form close, satisfying relationships (Szirom, 1988). 
Jacqueline J. Kacen Girrrl power and boyyy nature: the past, present, and paradisal future of consumer gender identity

Marketing Intelligence \& Planning

18,6/7 [2000] 345-355
3 A 1924 Pepsodent ad targeted to men proclaimed: "Dental science has found two ways daily to fight [tooth] film ... after many careful tests these methods were adopted". In addition to promoting a beauty ideal for women, these ads illustrate the sciencenature, rational-emotional dualist construction of gender identity.

4 Consistent with the literature, the word "utopia" is used here as a generic term for a fictitious or fantastic society; "dystopia" refers to a fictitious "bad" place that serves as a warning of where present society is headed; and "eutopia" denotes an idealized "good" place that is superior to the "real" world in which we live (see e.g. Relf, 1993; Sargent, 1988).

\section{References}

Archer, D., Iritani, B., Kimes, D.D. and Barrios, M. (1983), "Face-ism: fives studies of sex differences in facial prominence", Journal of Personality and Social Psychology, Vol. 45, pp. 725-35.

Baker, S. (1961), Visual Persuasion: The Effect of Pictures on the Subconscious, McGraw-Hill, New York, NY.

Bannon, L. (2000), "Why girls and boys get different toys: 'gender-neutral' is out, as more kids' marketers pitch single-sex products”, Wall Street Journal, 14 February, pp. B1, B4.

Barthel, D. (1994), "A gentleman and a consumer", in Maasik, S. and Solomon, J. (Eds), Signs of Life in the USA: Readings on Popular Culture for Writers, Bedford Books, Boston, MA, pp. 128-38.

Baudrillard, J. (1970), La Societe de Consommation, Gallimard, Paris.

Baudrillard, J. (1988), Selected Writings, Poster, M. (Ed.), Polity Press, Cambridge.

Baudrillard, J. (1996), Cool Memories II, trans. Turner, C., Duke University Press, Durham.

Belk, R.W. (1988), "Possessions and the extended self", Journal of Consumer Research, Vol. 15 No. 2, pp. 139-68.

Belk, R. and Bryce, W. (1993), "Christmas shopping scenes: from modern miracle to postmodern mall”, International Journal of Research in Marketing, Vol. 10, pp. 277-96.

Belk, R.W. and Costa, J.A. (1998), "The mountain man myth: a contemporary consuming fantasy", Journal of Consumer Research, Vol. 25 No. 3, pp. 218-40.

Bocock, R. (1993), Consumption, Routledge, London. Bordo, S. (1993), Unbearable Weight: Feminism, Western Culture, and the Body, University of California Press, Berkeley, CA.

Bourdieu, P. (1984), Distinction: A Social Critique of the Judgement of Taste, trans. Nice, R., Harvard University Press, Cambridge.

Bristor, J.M. and Fischer, E. (1993), "Feminist thought: implications for consumer research", Journal of Consumer Research, Vol. 19 No. 4, pp. 518-36.

Brod, H. (1995), "Masculinity as masquerade", in Perchuk, A. and Posner, H. (Eds), The Masculine Masquerade: Masculinity and Representation, MIT Press, Cambridge, pp. 13-19.

Brown, S. (1999a), "Premonitions of paradiso: millenial madness, fin de siecle fever and the end of the end of marketing", in Brown, S. and Patterson, A. (Eds), Proceedings of the Marketing Paradiso Conclave, University of Ulster, Belfast, pp. 1-13.

Brown, S. (1999b), "Retro-marketing: yesterday's tomorrows, today!", Marketing Intelligence and Planning, Vol. 17 No. 7, pp. 363-76.

Butler, J. (1990), Gender Trouble, Routledge, New York, NY.

Chodorow, N.J. (1996), "Gender as a personal and cultural construction", in Joerer, R.B. and Laslett, B. (Eds), The Second Signs Reader: Feminist Scholarship 1983-1996, University of Chicago Press, Chicago, IL, pp. 216-44.

Cohan, S. (1993), "Masquerading as the American male in the fifties: Picnic, William Holden and the spectacle of masculinity in Hollywood film”, in Penley, C. and Willis, S. (Eds), Male Trouble, University of Minnesota Press, Minneapolis, MN, pp. 203-32.

Conley, V. (1984), Helene Cixous: Writing the Feminine, University of Nebraska Press, Lincoln, NE.

Currie, D.H. (1997), "Decoding femininity: advertisements and their teenage readers", Gender \& Society, Vol. 11 No. 4, pp. 453-77.

D'Andrade, R.G. (1974), "Sex differences and cultural institutions", in LeVine, R.A. (Ed.), Culture and Personality: Contemporary Readings, Aldin, Chicago, IL, pp. 16-39.

Danet, B. and Ruedenberg, L. (1994), “'Smoking dope' at a virtual party: writing, play and performance on Internet relay chat", in Rafaeli, S. et al. (Eds), Network and Netplay: Virtual Groups on the Internet, MIT Press, Cambridge.

Ehrenreich, B. (1983), The Hearts of Men: American Dreams and the Flight from Commitment, Doubleday, New York, NY.

Elliott, R. (1993), "Marketing and the meaning of postmodern culture", in Brownlie, D., Saren, M., Wensley, R. and Whittington, R. (Eds), Rethinking Marketing: New Perspectives on the Discipline and Profession, Warwick Business School, Coventry, pp. 134-42.

Epstein, C. (1988), Deceptive Distinctions: Sex, Gender, and the Social Order, Yale University Press, New Haven, CT.

Fetto, J. (1999), "But made for a man", American Demographics, December, pp. 11-12.

Firat, A.F. (1998), "The power of objectification: consuming the feminine", in Fischer, E. and Wardlow, D.L. (Eds), Gender, Marketing and Consumer Behavior Proceedings of the Fourth Conference, San Francisco State University, San Francisco, CA, pp. 225-31.

Firat, A.F. and Venkatesh, A. (1993), "Postmodernity: the age of marketing", International Journal of Research in Marketing, Vol. 10, pp. 227-49.

Foucault, M. (1980), Power/Knowledge, Pantheon Books, New York, NY.

Ger, G. and Belk, R.W. (1996), "I'd like to buy the world a Coke: consumptionscapes of the 'less affluent world"', Journal of Consumer Policy, Vol. 19 No. 3, pp. 271-304.

Gergen, K.J. (1991), The Saturated Self: Dilemmas of Identity in Contemporary Life, Basic Books, New York, NY.

Giddens, A. (1991), Modernity and Self Identity, Polity, Cambridge. 
Jacqueline J. Kacen Girrrl power and boyyy nature: the past, present, and paradisal future of consumer gender identity

Marketing Intelligence \& Planning

18,6/7 [2000] 345-355
Gilmore, D.D. (1990), Manhood in the Making: Cultural Concepts of Masculinity, Yale University Press, New Haven, CT.

Gledhill, C. (1997), "Genre and gender: the case of the soap opera”, in Hall, S. (Ed.), Representation: Cultural Representations and Signifying Practices, Sage, London, pp. 337-84.

Goffman, E. (1959), The Presentation of Self in Everyday Life, Anchor Books, New York, NY.

Hanke, R. (1998), “The 'mock-macho' situation comedy: hegemonic masculinity and its reiteration", Western Journal of Communication, Vol. 62 No. 1, pp. 74-93.

Hare-Musten, R.T. and Marecek, J. (1998), "The meaning of difference: gender theory, postmodernism, and psychology", in Clinchy, B.M. and Norem, J.K. (Eds), The Gender and Psychology Reader, New York University Press, New York, NY, pp. 125-58.

Harris, J.R. (1998), The Nurture Assumption, Free Press, New York, NY.

Hirschman, E.C. (1993), "Ideology in consumer research, 1980 and 1990: a Marxist and feminist critique", Journal of Consumer Research, Vol. 19 No. 4, pp. 537-55.

Jaffe, J.M., Lee, Y.E., Huang, L.N. and Oshagan, H. (1995), "Gender, pseudonyms, and CMC: masking identities and baring souls", International Communication Association Conference, Albuquerque, NM.

Joy, A. and Venkatesh, A. (1994), "Postmodernism, feminism, and the body: the visible and the invisible in consumer research", International Journal of Research in Marketing, Vol. 11, pp. 333-57.

Katz, P.A. (1986), "Gender identity: development and consequences", in Ashmore, R.D. and Del Boca, F. K. (Eds), The Social-Psychology of Female-Male Relations: A Critical Analysis of Central Concepts, Academic Press, New York, NY, pp. 2-67.

Kellner, D. (1992), "Popular culture and the construction of postmodern identities", in Lash, S. and Friedman, J. (Eds), Modernity and Identity, Blackwell, Oxford.

Kristeva, J. (1980), Desire in Language: A Semiotic Approach to Literature and Art, Blackwell, Oxford.

Kumar, K. (1993), "The end of socialism? The end of utopia? The end of history?", in Kumar, $\mathrm{K}$. and Bann, S. (Eds), Utopias and the Millenium, Reaktion Books, London, pp. 63-80.

Lacan, J. (1977), "The signification of the Phallus”, trans. Sheridan, A., in Ecrits: $A$ Selection, W.W. Norton, New York, NY.

Lippert, B. (1997), "Pecsploitation”, New York, 31 March, pp. 22-3.

Lovell, T. (1996), "Feminist social theory", in Turner, B. (Ed.), The Blackwell Companion to Social Theory, Blackwell, Oxford.

Lowry, R. (1997), “Ab nauseam”, National Review, 13 October.

Lyon, D. (1999), Postmodernity, University of Minnesota Press, Minneapolis, MN.

MacKenzie, G.O. (1994), Transgender Nation, Bowling Green State University Popular Press, Bowling Green, OH.

Manuel, F.E. (1966), Utopias and Utopian Thought, Houghton Mifflin, Boston, MA.

Manuel, F.E. and Manuel, F.P. (1979), Utopian Thought in the Western World, Belknap Press, Cambridge, MA.
Marchand, R. (1985), Advertising the American Dream, University of California Press, Berkeley, CA.

McCracken, E. (1993), Decoding Women's Magazines: From Mademoiselle to Ms., Macmillan, London.

McCracken, G. (1988), Culture and Consumption, Indiana University Press, Bloomington, IN.

McLuhan, M. (1951), The Mechanical Bride: Folklore of Industrial Man, Vanguard Press, New York, NY.

Mort, F. (1988), "Boy's Own? masculinity, style, and popular culture," in Chapman, R. and Rutherford, J. (Eds), Male Order, Lawrence and Wishart, London.

Mucchielli, R. (1961), Le Mythe de la Cite Ideale, University of France Press, Paris.

Raymond, J. (1999), “20/20 vision”, American Demographics, December, pp. 46-55.

Reilly, R. (1999), “The goal-goal girls”, Sports Illustrated, 5 July, p. 100.

Relf, J. (1993), "Utopia the good breast: coming home to Mother", in Kumar, K. and Bann, S. (Eds), Utopias and the Millenium, Reaktion Books, London, pp. 107-128.

Sargent, L.T. (1988), British and American Utopian Literature, 1516-1985: An Annotated, Chronological Bibliography, Garland, New York, NY.

Seabrook, J. (1999), "Nobrow culture", The New Yorker, 20 September, pp. 104-11.

Smith, S.G. (1992), Gender Thinking, Temple University Press, Philadelphia, PA.

Spence, J. and Helmreich, R. (1978), Masculinity and Femininity: Their Psychological Dimensions, Correlates and Antecedents, University of Texas Press, Austin, TX.

Stewart, A.J. (1998), "Doing personality research: how can feminist theories help?", in Clinchy, B.M. and Norem, J.K. (Eds), The Gender and Psychology Reader, New York University Press, New York, NY, pp. 54-68.

Szirom, T. (1988), Teaching Gender, Allen \& Unwin, Boston, MA.

Taylor, M. and Saarinen, E. (1994), Imagolies: Media Philosophy, Routledge, London.

Thompson, C.J. and Hirschman, E.C. (1995), "Understanding the socialized body: a poststructuralist analysis of consumers' selfconceptions, body images, and self-care practices", Journal of Consumer Research, Vol. 22 No. 2, pp. 139-53.

Tseelon, E. (1995), The Masque of Femininity, Sage, Thousand Oaks, CA.

Unger, R. and Crawford, M. (1992), Women \& Gender: A Feminist Psychology, McGraw Hill, New York, NY.

West, C. and Zimmerman, D.H. (1998), "Doing gender", in Clinchy, B.M. and Norem, J.K. (Eds), The Gender and Psychology Reader, New York University Press, New York, NY, pp. 104-24.

Williams, J. (1979), "Psychological androgyny and mental health", in Hartnett, O. et al. (Eds), Women: Sex Role Stereotyping, Tavistock, London.

Woodhouse, A. (1989), Fantastic Women, Macmillan, London.

Wright, R. (2000), "Will we ever log off?”, Time, 21 February, pp. 56-8.

Yorburg, B. (1974), Sexual Identity: Sex Roles and Social Change, Wiley, New York, NY. 